\title{
Reflection of mining in mining and post-mining landscapes using cartographic sources
}

\author{
Jakub Jelen ${ }^{1, *}$, Miroslav Čábelka²
}

\author{
1 Department of Social Geography and Regional Development, Charles University, Faculty of Science, Czechia \\ 2 Department of Applied Geoinformatics and Cartography, Charles University, Faculty of Science, Czechia \\ * Corresponding author: jakub.jelen@natur.cuni.cz
}

\begin{abstract}
This article compares mining and post-mining landscapes on old maps and in modern aviation photography of three regions around the towns of Jáchymov, Most and Kladno in Czechia. The three regions differ not only in the type of mining, but also in their historical development and current management. The goal of the article is to compare these regions and evaluate the changes and consequences of mining on the landscape in different time periods using cartographic sources. Another aim is to identify specific landscape elements related to mining by drawing on old maps and state map series of the three regions.
\end{abstract}

\section{KEYWORDS}

mining; cartographic sources; old map; historical cartography; historical geography

Received: 1 June 2020

Accepted: 1 December 2020

Published online: 18 December 2020

Jelen, J., Čábelka, M. (2021): Reflection of mining in mining and post-mining landscapes using cartographic sources.

AUC Geographica 56(1), 44-55

https://doi.org/10.14712/23361980.2020.23

(C) 2021 The Authors. This is an open-access article distributed under the terms of the Creative Commons Attribution License (http://creativecommons.org/licenses/by/4.0). 


\section{Introduction}

Human socio-economic activities have shaped different types of cultural landscapes for centuries. Agricultural, industrial, transportation and other activities change the landscape and leave their imprints even years or centuries after they are over (Taylor 2003). Different types of cultural landscapes reflect specific human activities (or their combination) and they can also remind us of the past that is imprinted in them. Documentation and identification of different types of landscapes help to maintain cultural memory of the landscape heritage (Ashworth, Graham 1997; Harvey 2008; Hewison 1989).

Apart from food production, mining is considered one of the oldest human activities and it can be documented already in the Stone Age (Mrázek 1996; Přichystal 2002). Since the ancient times, people have been acquiring different raw materials in order to hunt, build shelters or craft tools. The three prehistoric periods are even named after important materials (Stone Age, Bronze Age, Iron Age). During the development of society, mining has gained importance, together with discoveries of chemical elements or resources. The presence of raw materials in a territory determines its economic development; it has an impact on the inhabitants and the landscape (Kopačka 1996). Mining is important mainly because it makes the industrial production possible and therefore it is a sort of a starter of any production or even industrialization itself.

Mining raw materials usually means substantial changes in the environment and it creates a new type of landscapes - mining landscapes. The end of mining is then usually related to massive investments in restoration, increase in unemployment or social and environmental problems (Bridge 2004). The end of mining can also be perceived as a new opportunity to create a post-mining landscape with particular characteristics. Such landscape can be, when properly managed, converted and used as a fully-fledged cultural landscape. This process always depends on specific conditions, for instance the raw material mined or the technique of mining (underground or surface mining, chemical or mechanical mining, etc.). Time and extent also play a role. Mining and post-mining landscapes need to be perceived as complexes of tangible and intangible landscape elements that reflect their past and represent certain values and meanings (Daugstad, Grytli 1999; Conesa, Schulin, Nowack 2008).

One way of observing changes in (not only) mining landscapes is to use modern technologies to compare old maps or to compare maps with aerial photographs (Niederöst 2004). The scope of this article is to use different cartographic sources to identify landscape elements related to mining in the selected areas and to discuss the use of cartographic sources for research on mining landscapes. Another aim is to use selected old maps and state map series of the three regions to present specific landscape elements in the territories and to discuss the possibilities of these products for the study of mining landscapes. The article compares three selected regions around the towns of Jáchymov, Most and Kladno, comparing mining and post-mining landscapes on old maps and in modern aviation photography. The three regions differ above all in the type of mining, but also in their historical development as in their current management. The scope of the article is to compare the regions and evaluate the changes and consequences of mining for the landscape in different time periods using cartographic sources. Selected regions represent territories that are studied within the project of the Ministry of Culture of the Czech Republic "NAKI II" called: Heritage of Lost Landscapes: Identification, Reconstruction and Presentation.

\section{Theoretical-methodological framework}

Currently, mining landscapes are studied within different disciplines and from different points of view. Cultural geography, for example, has moved from the perception of mining activities and their relicts as only industrial activities to the perception of these as parts of culture as well. Definitions of specific cultural and social values related to mining are made. Mining has brought specific types of miners' settlement and communities. If the relicts of mining activities are maintained, interpreted or reused, it is possible to speak about mining heritage (Conesa, Schulin, Nowack 2008; Coupland, Coupland 2014; Turnpenny 2004; Jelen 2018).

When managing mining landscapes, it is possible to use the relicts as part of culture and society, e.g. for tourism (Cole 2004; Coupland, Coupland 2014; Conlin, Jolliffe 2014). One of the clearest examples is the conversion of the German mines Zollverein in Essen. After the mining finished, the mines were converted into one of the most attractive places of industrial history. Cultural and social events are held there, there are a museum of design and many other places of interest: restaurants, concert halls, theatres, conference venues, etc. Zollverein was inscribed into the UNESCO list of World Heritage Sites in 2001.

When researching mining landscapes, it is important to analyze values and meaning of areas as well as its development and changes. Historical geography and historical cartography provide tools for such research that enable us to understand the processes in the past and use them to explain and understand the current state of these landscapes.

Thanks to historical geographical analysis, it is possible to compare and research development of areas. Such knowledge is important for realizing values and meanings of an area, maintaining landscape heritage and responsible management. It also allows 
a combination of time and space organisation of processes, one of the main tasks of historical geography and cartography (Schenk 2011; Jelen 2018).

\section{Cartographic sources as a source of information about mining landscapes}

Historical geography uses a diverse range of historical geographical sources that include not only historical sources, but also sources from related technical disciplines and natural sciences (Semotanová 2006). The sources of information about the past can be categorized in multiple ways. Most commonly, the categories are the following: tangible sources, written sources, and images/iconographic sources that include a distinct group of cartographic sources. These are old maps that provide valuable information about the shape of landscapes in the past and that help us to trace anthropogenic landscape changes. They can provide visual information about landscapes and specific buildings as well as processes in the past and about the ways they were captured in maps (Tůmová 2018; Win 2014). The most useful and the most used categories of cartographic sources are so called comparative sources (e.g. Müller's survey, military surveys, Stable Cadastre or old aerial photographs and orthophotography) and individual sources (e.g. Klaudyán's map of Bohemia, Aretin's map of Bohemia, Vogt's map of Bohemia). This division is related to the evolution of map production as individuals were the first ones to initiate creating maps, followed only later by state institutions (Tůmová 2018).

\subsection{The oldest maps of Bohemia - individual maps}

The first maps with simple thematic map elements, mostly related to economic activities, but also to cultural ones, appeared in the Czech lands already at the beginning of map production in the 16th and 17th century. These old maps, together with written and iconographic materials, allow a complex study of scarcely studied pre-industrial landscapes. They can also contribute to improve the knowledge and reconstruction of the past landscapes and also to evaluate long-term changes of landscapes. They also provide material for discussion on relationships, approaches and landscape protection and protection of landscape heritage in the present and the future (Marcucci 2000; Antrop 2005).

In the early modern period (from the 16 th to the 18th century), there were mostly individual maps made. Cartographic research on semiotic and cartometric analyses of selected old maps uses mostly individual maps of early modern period (Bayer 2009; Potůčková 2012; Semotanová 2001). The oldest maps of Bohemia, e.g. Klaudyán's map, Aretin's map, Vogt's map, do not, however, provide much detailed and accurate information about landscape (Mucha 1992; Kuchař 1959). But many of them already include cartographic symbols to provide information about locations of raw materials and about mining activities.

The first testimony of mining activities and sources of raw material in Bohemia is found in the third oldest individual map of Bohemia that was published in 1619. Its original title was Regni Bohemiae Nova et Exacta Descriptio, i.e. New and Accurate Description of the Bohemian Kingdom. Its author was Pavel Aretin from Ehrenfeld and the scale was set by Karel Kuchar to be $1: 504,000$.

The Pavel Aretin included names of 1,200 settlements, mostly in Czech, but also in German. The elevation is depicted by hill profiles. The map legend (figure 1) contains 16 symbols for free royal towns, royal towns, serfdom town (2 symbols), villages, castles, forts, monasteries, towns with castles, villages with castles, deposits of gold, silver, tin and iron ore, spa and glass production (Kuchař 1936).

In the 18th century, the cartographers started to use new symbols also for important economic, natural and cultural processes. The example is the map by Johann Gregor Vogt published in 1712. The map's

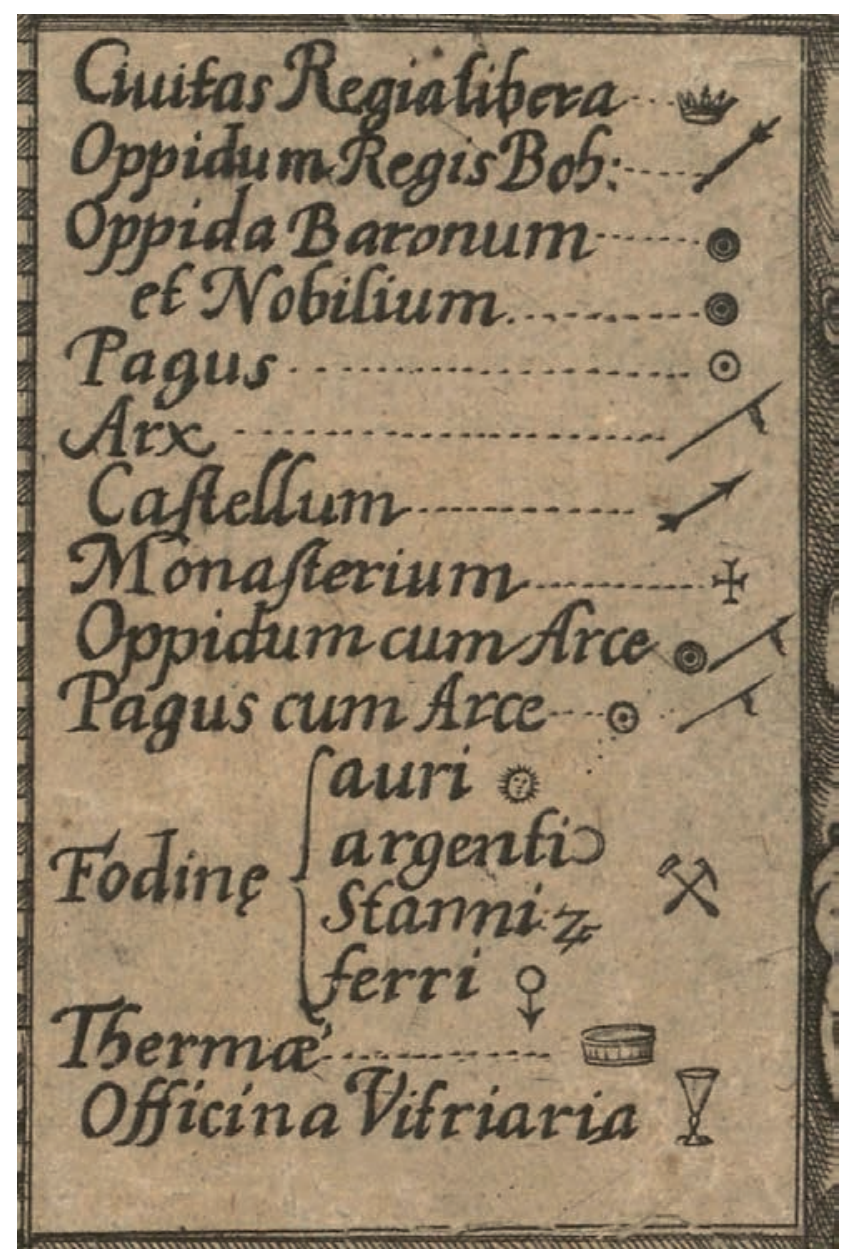

Fig. 1 The legend of Aretin's map of Bohemia (1632) with symbols for deposits of raw materials.

Source: The Map Collection of the Faculty of Science, Charles University 


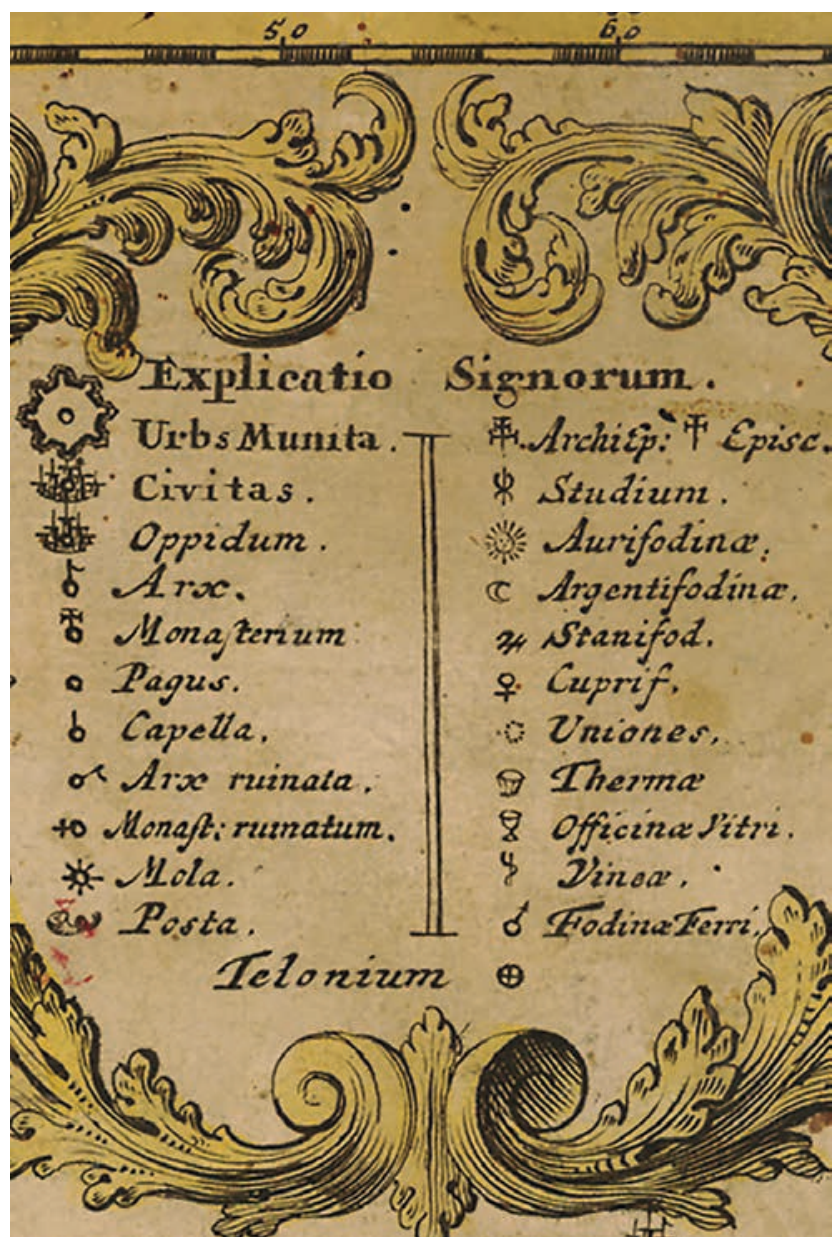

Fig. 2 The legend of Vogt's map of Bohemia (1712) with symbols for deposits of raw materials.

Source: The map collection of the Faculty of Science, Charles University

dimension are $853 \times 656 \mathrm{~cm}$, the scale at the central meridian is $1: 396,800$ (Bayer 2009). It is a thematic map of Bohemia with elevation depicted by hill profiles. In the map legend, Vogt included 24 map symbols (figure 2): towns with fortification, towns without fortification, castles, monasteries, villages, chapels, ruins of castles, castles and monasteries, mills, post offices, dioceses and archdioceses, Latin schools, deposits of gold, silver, tin, copper, locations of pearl mussels, hot springs, glass production, vineyards, iron smelters and customs (Kuchař 1959; Novotná 2020).

The map of the Bohemian Kingdom (Mappa Geographica Regni Bohemiae) published in 1720 by Jan Kryštof Müller is considered one of the most important cartographic works of Czech history. The map is divided into 25 sheets and its dimensions are $282.2 \times 240.3 \mathrm{~cm}$. The scale is around $1: 132,000$ (Kuchař 1959). The map was ordered by the state (the Austrian Empire) to map military, administrative and economic features. That is why there is not only detailed topographic information (settlements, water, elevation, vegetation, roads), but also farms, abandoned settlements, mills, vineyards, mines of gold, silver, tin, copper and iron, brass casting, hammer

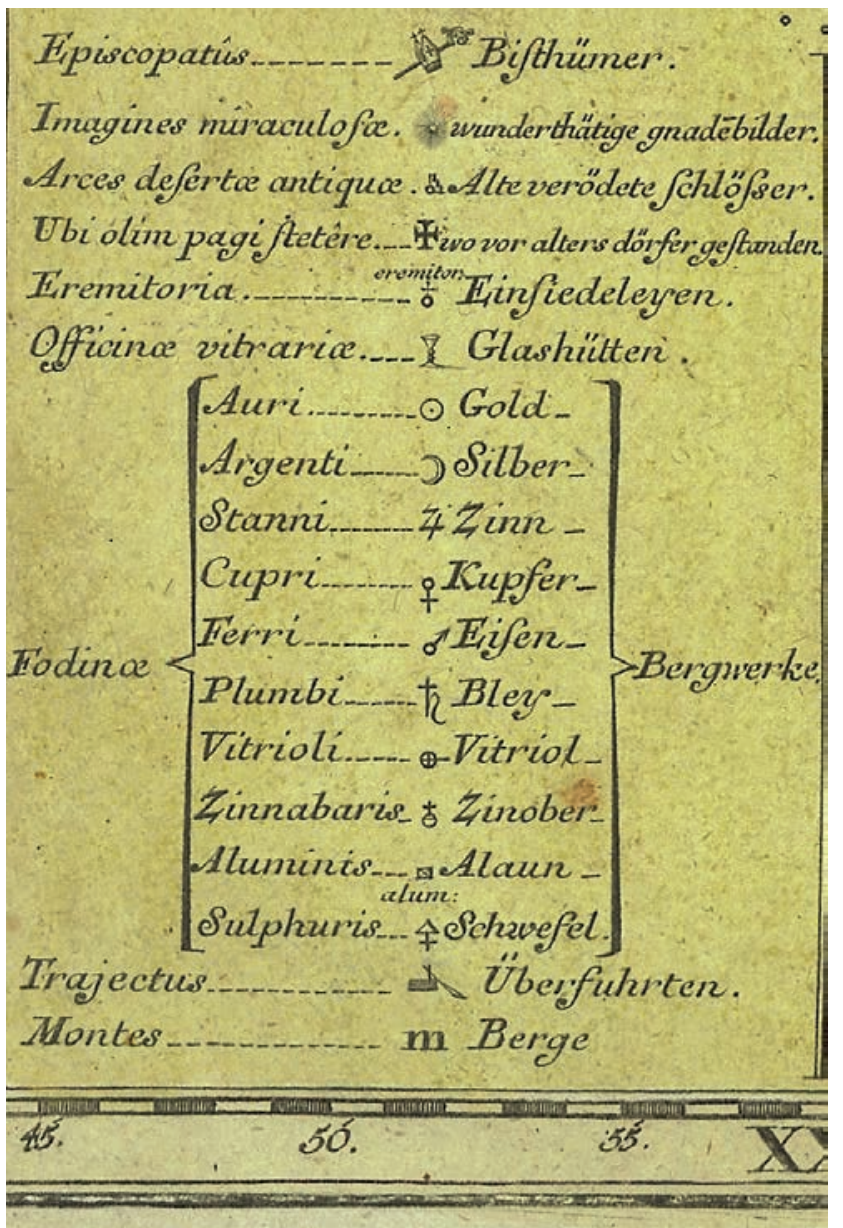

Fig. 3 A part of the map legend of Müller's map of Bohemia (1720) with symbols for deposits of raw materials.

Source: The map collection of the Faculty of Science, Charles University

mills, iron smelters, glass production, post offices and others. As the approved symbols were not enough for Müller, he added written information in the maps or used different symbols than those in the map legend. According to Kucharr (1959), the map includes the total of 12,495 places with names and the map legend describes (in Latin and in German) 48 well selected symbols (figure 3 ).

The explanations in the map prove the importance of raw materials for the economy at the time. The most important were the deposits of gold, silver, iron ore, copper, alum, sulphates and related places of metalworking (Semotanová 2011). Müller's map is more detailed compared to the ones by Aretin and Vogt, also thanks to its scale. The map legend maintains the symbol of two crossed hammers as the symbol of mining.

\subsection{State map series from the second half of the 18th century}

State map series cover larger areas, usually whole countries, using the same map projection, scale and usually also the same legend. Among these series, 
we can already find the first maps by Jan Kryštof Müller, then military surveys, Stable Cadastre, sets of aerial photography, newer maps of larger areas (for instance regions) and of course the newest state map series. Such series, called comparative cartographic sources, allow wider comparative research (Tůmová 2018). Important comparative sources on the territory of Bohemia are the map series created and used between the mid-18th century and the beginning of the 20th century. These sources are so called military surveys whose scale is suitable for landscape studies. Combined with Stable Cadastre sources, they are a wonderful starting point for the study of landscape changes in the modern period. On these maps, we can observe buildings and building complexes that have undergone many changes or have disappeared, partially or completely (Hauserová 2015).

\subsubsection{Military surveys}

The three military surveys were the first attempt to capture the whole area of the Habsburg Monarchy. They were done because of an urgent need to have a unified map system for military purposes. The first military survey was done between the 1760 s and 1780 s with the scale $1: 28,800$. It captures the baroque landscape at the end of the early modern period still with some remainders of the feudal relations.

The second military survey was done between 1806 and 1869 in the territory of Austria-Hungary. The scale was the same, i.e. $1: 28,800$. The mapping was based on an accurate trigonometric net and it was based also on the map documentation of the Stable Cadastre (see below). Due to the time period that elapsed from the first survey, the object of the mapping was the landscape of the Czech lands in the time of the Industrial Revolution. The content of the survey is basically the same as of the first one. It contains roads, brick buildings, and stone bridges. The natural elements included are fields, meadows, woods, ponds and watercourses. The elevation is indicated by Lehmann's slope hachures.

The third military survey of Austria-Hungary was done between 1869 and 1885 when the number of new railways, roads, ore and coal mines, industrial projects and plans to make some of the rivers navigable required precise topographic information (Hauserová 2015). The new survey had the scale of $1: 25,000$. Compared to the second survey, the elevation is recorded in a better way - not only by hachures, but also by contour lines and spot heights. The result of the survey are coloured so called topographic sections that were reprinted in special maps $(1: 75,000)$ and general maps $(1: 200,000)$. The survey was once again based on the Stable Cadastre.

The third survey managed to capture the period of intensive industrialization of the Czech lands - this is visible mainly at the edges of cities and town. The landscape on the map is full of different types of roads. Mining and processing of raw materials is increasingly intensive. The map legend is very detailed and as such it provides deep insight into types of soils, vegetation, structure of settlements and sometimes even into functions of different buildings. The agricultural land, on the other hand, did not change significantly compared to the second survey (Hauserová 2015; Semotanová 2006).

\subsubsection{Stable Cadastre}

Information about all the land in the Austrian Empire was included in the Stable Cadastre whose scope was to provide exact documentation for land taxation. The mapping of Bohemia took place from 1826 to 1830 and again from 1837 to 1843 . The scale was $1: 2,880$.

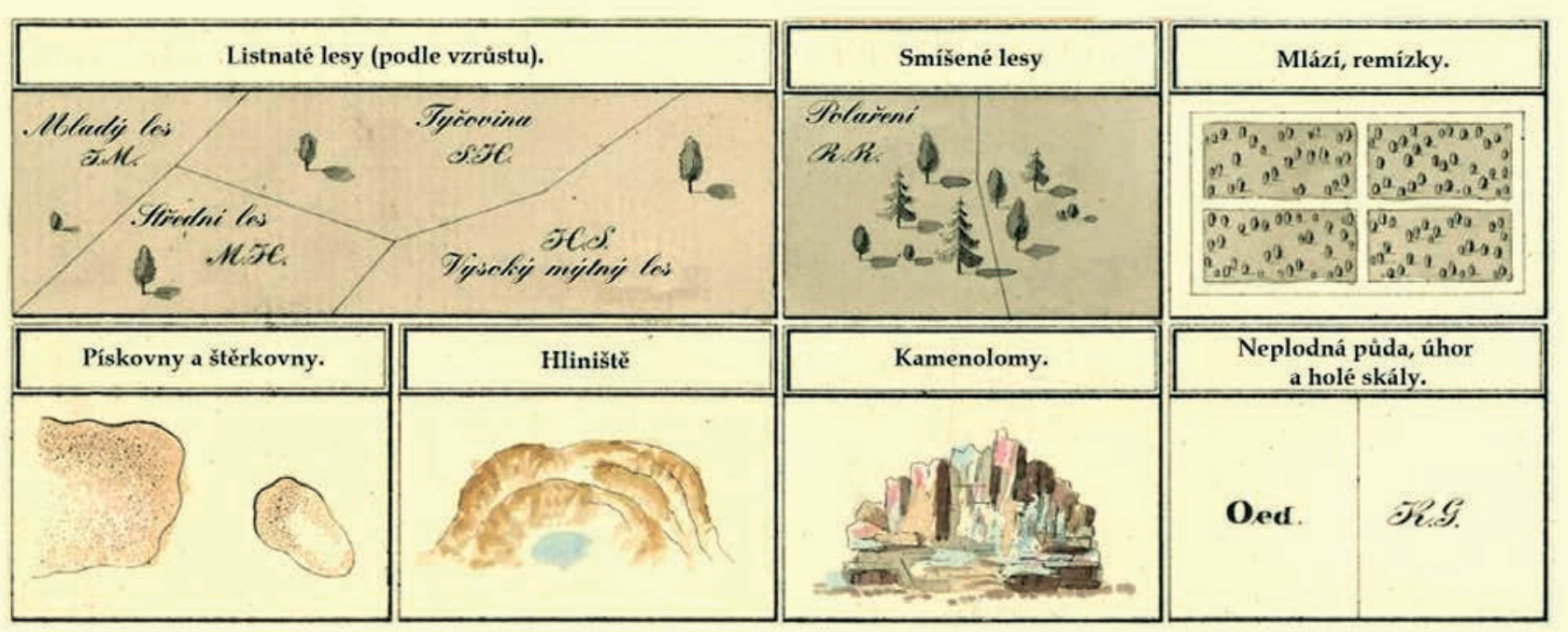

Fig. 4 Part of the map legend of the Stable Cadastre with symbols for surface mines. First row: deciduous forests (by growth), mixed forests, thickets, draws; second row: sand pits and gravel pits, clay pits, quarries, barren soil, fallow land.

Source: The Map Collection of the Faculty of Science, Charles University 
One cadastral map was made for each municipality and its land lots, including all the borderlines. Due to the need to express the value of each lot, the land cover and land use were documented very precisely and in much detail. The cadastral maps capture the Czech lands in the time of intensification of agriculture and beginning of the Industrial Revolution. Due to the scope of the cadastre (taxation), there is no information about elevation. The maps were made with a single map legend and the same colours (figure 4). For example brownish grey is used for woods, bright green for parks, gardens and meadows, ochre for fields, light green for pastures (with letters G or GW which signal municipal pastures). Carmine is used for brick buildings, stone bridges, weirs and roads, dark carmine for public buildings, yellow for wooden buildings and bridges. White is used courtyards and squares and brown is used for roads, blue for water (Plánka 2014). As for the surface mines, the maps include clay pits, stone, sand and gravel quarries that are indicated by symbols (figure 4).

\subsubsection{Aerial photographs}

It is possible to compare the information from old maps with newer or modern maps. From the documentation that is easily, it is necessary to point out the importance of orthophotographs of the surface of Czechia that have been taken from 1936 onwards (with only a break during the Second World War) for military purposes. The photographs are archived in the Military Geographical and Hydrometeorological Institute in Dobruška (VGHMÚř in Dobruška 2020).

The next military survey was done in the 1950s. The result was the first Czechoslovak map series of the whole country done by aerial photogrammetry. It is a unique representation of the country before the post-1948 societal changes could be reflected in the landscape. The collectivization of agriculture was still not much visible in the photographs and the towns were captured before the construction of flat complexes. The photographs capture in detail mountain landscapes and it is possible to identify mines, mining operations and other elements.

\subsubsection{Contemporary orthophotography of Czechia} Orthophotography of the Czech Republic is a periodically updated set of coloured orthophotographs in the same format of the state map, i.e. $1: 5,000(2 \times 2.5 \mathrm{~km})$. The photographs are coloured and georeferenced representation of the Earth's surface. Each zone reflects the territory in the same year. Since 2016, the orthophotographs have been made in pixel $0.2 \mathrm{~m}$. Moreover, the photographs have been taken with a digital camera since 2010 and as a result, the quality of photographs has been much higher (Geoportál ČUZK 2020). Since 2003, the orthophotographs have been provided by the State Administration of Land Surveying and Cadastre and the Military Geographical and
Hydrometeorological Institute. As of 2012, the photographs of Czechia and the preparation of the orthophotographs are done every two years. Each year, half of the territory is photographed.

\section{Analysis of the sample territories}

Three locations in Czechia were chosen for the comparative study. They have all been changed by intensive mining. Each of them represents a different raw material, historical period and method of mining. Thanks to that, it is possible to compare the way mining was reflected in different map series and what landscapes changes have occurred in relation to mining. For the comparison, the Stable Cadastre, the third military survey, aerial photographs from the 1950s and current orthophotography were used.

\subsection{The region of Jáchymov}

The first region is the region of Jáchymov in the Ore Mountains. It is an area with the oldest mining history in Czechia. The first evidence of mining dates back to 1300 (Hloušek 2017). At the beginning of the 16 th century, the mining of silver ores expanded and Jáchymov became the second biggest town in the Bohemian Kingdom after Prague as it had almost 25,000 inhabitants. During the same century, many new mines were founded and the centre of the miners' town was built. There was also a new royal mint built to produce silver coins - thalers. The mining is documented already in the oldest maps. In the Aretin map we can see two simple symbols: crossed hammers for a mine and a moon for the material, i.e. silver (see figure 5). Müller's survey uses only the symbol for silver (moon), but it is used five times in the region (see figure 7) to emphasize the extent of mining in the area. Also in Vogt's map of Bohemia, the

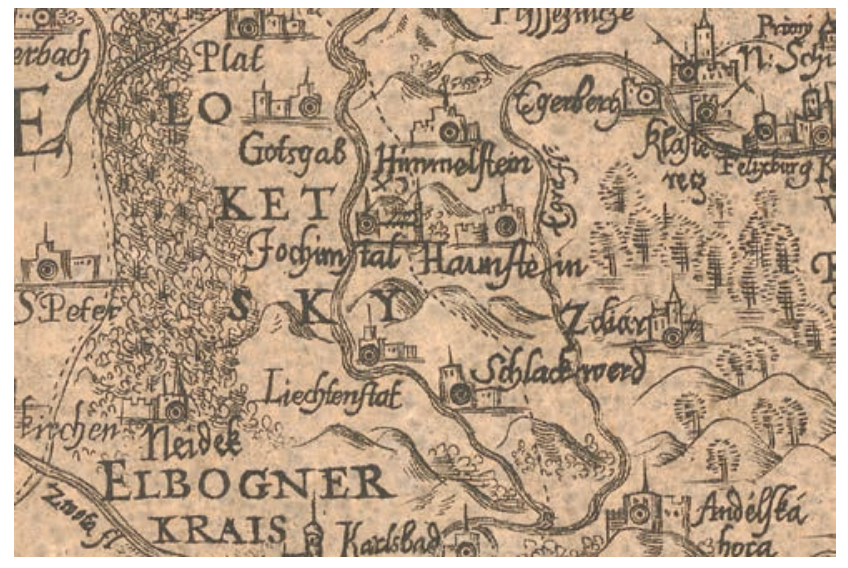

Fig. 5 Silver mining in the Jáchymov region in Aretin map of Bohemia (1632).

Source: The Map Collection of the Faculty of Science, Charles University 


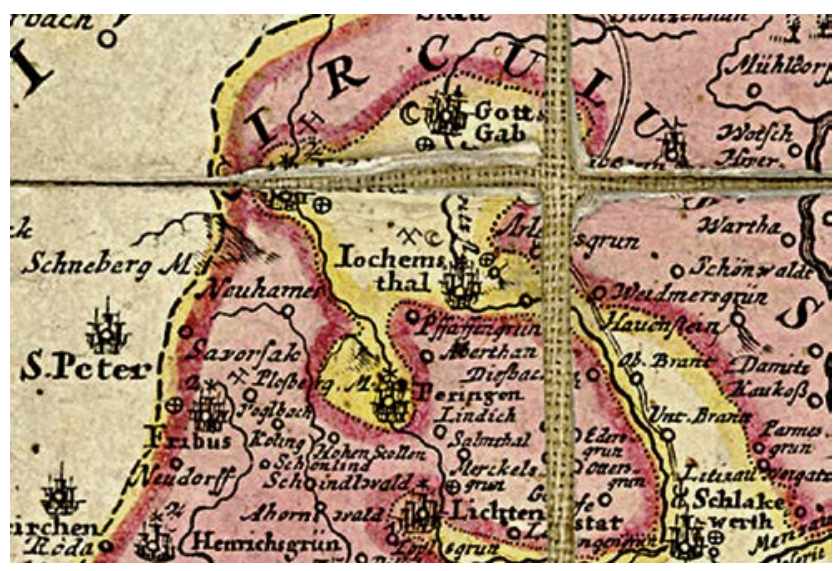

Fig. 6 Silver mining in the Jáchymov region in Vogt's map of Bohemia (1712).

Source: The Map Collection of the Faculty of Science, Charles University

mining in Jáchymov is documented by two symbols: crossed hammers for a mine and a moon for silver (see figure 6).

When the deposits of silver were used, the mining in the region continued from the 17 th to the 19 th century with cobalt, bismuth, nickel, tin, and later also uranium. Since the mid-19th century, radioactive materials were mined. Firstly, to be used in uranium colours, later for extraction of radium and in the mid20th century the uranium was extracted for military purposes. The last period of mining between 1945 and 1964 changed the landscape the most as it was very intensive mining of uranium ores to be used in the former USSR. After 1945, more than 25 mines were opened in the region, more than 1,000 kilometres of shafts and 8,000 tons of uranium were excavated (Jelen, Kučera 2017). The landscape was changed the most by huge soil tips, but also by new buildings intended for separation and elaboration of ores. In relation to the uranium extraction, there were large numbers of miners working in the Jáchymov region. Some of them were prisoners convicted for both political and non-political crimes. The prisoners lived in labour camps - there were dozens of them around Jáchymov (Hloušek 2017).

After the uranium deposits were gone, the communist government wanted to delete all the traces of mining that remained in the landscape. The mines were destroyed; labour camps were razed to the ground. The uranium mines were supposed to be forgotten. This is documented also by construction of new cottages and recreation areas in the place where the mines and labour camps had been (Hloušek 2017). The situation changed in 1989 and the remaining traces of the mining started to be used to remember the local heritage. The idea is to protect the landscape that witnessed more than 800 years of mining and keep it as a complex. The highlight of these attempts was the inscription of the landscape of Krušnohoří/

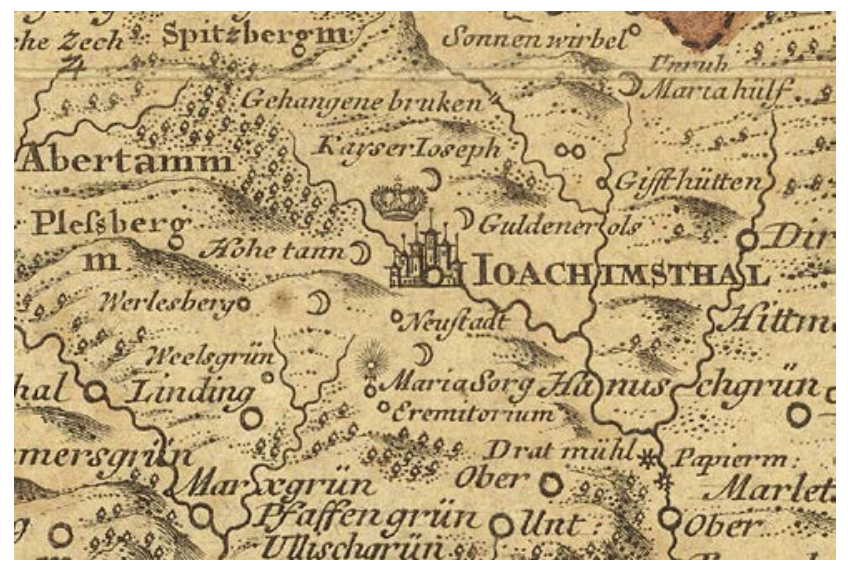

Fig. 7 Silver mining in the Jáchymov region in the Müller's survey of Bohemia (1720).

Source: The Map Collection of the Faculty of Science, Charles University

Erzgebirge in the UNESCO World Heritage List in 2019 (Karel, Kratochvílová 2013; Jelen, Chromý 2018, UNESCO 2020).

When comparing the cartographic sources, it is possible to see that the landscape right around the historical centre of Jáchymov is labelled as a place of silver mining in the Stable Cadastre (figure 8). The soil tips on the hillside of Kailberg, to the west from the church, are partly covered with grass. There are pastures ( $W$ - Weiden) and rubble ( $E$ - Egärten). However, some hillsides are still bare and rocky - and not fertile (Ö - Öde). The large soil tip with the soil from the closest mine Svornost is also marked as not fertile (1). In contrast to the current situation, there are no woods on the hills above the town because wood was commonly used in the mine constructions. On the platform above the square, a horse mill was still maintained in the time of mapping (2). The horse mill provided vertical communication in the silver mine of the Emperor Joseph II. The map of the third military survey documents the mining with the symbol of crossed hammers (figure 9). The soil tips are indicated by contour lines and hachures, but they are not labelled, therefore it is almost impossible to identify them without previous knowledge of the area. The uranium extraction is then visible in the orthophotograph from 1953 (figure 10). In the photograph, there is also visible the labour camp Svornost (next to the mine Svornost). The current state of the landscape is documented by the orthophotograph from 2019 (figure 11). The soil tip of Svornost is covered with wood and the grasslands are used as pastures. There are almost no remainders of the labour camp. After careful examination, it would be possible to recognize parts of fences, which, however, are not original, but they are from 2016 when some parts of the labour camp were renewed to serve as a memorial to the suffering of the political prisoners from the 1950s and 1960s (Jelen, Chromý 2018). 


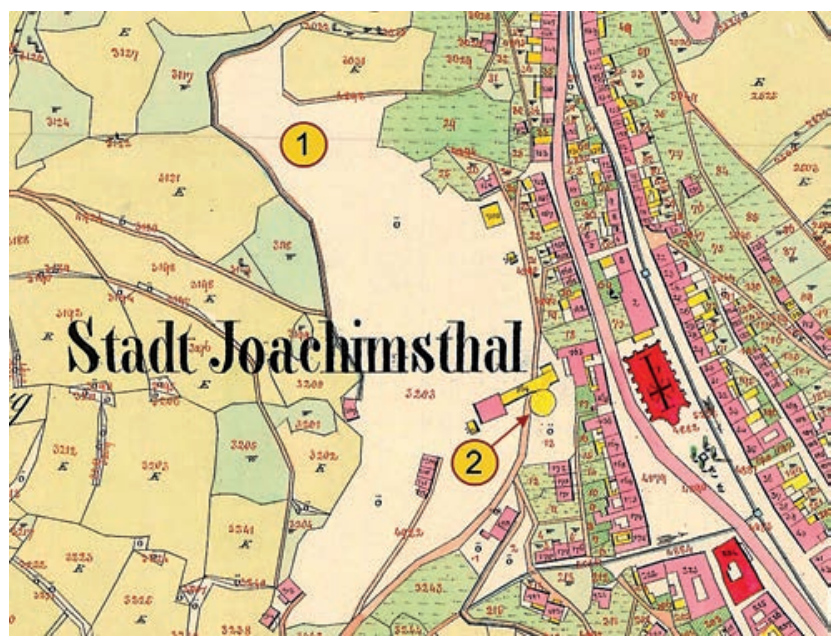

Fig. 8 The centre of Jáchymov in the Stable Cadastre.

Source: State Administration of Land Surveying and Cadastre

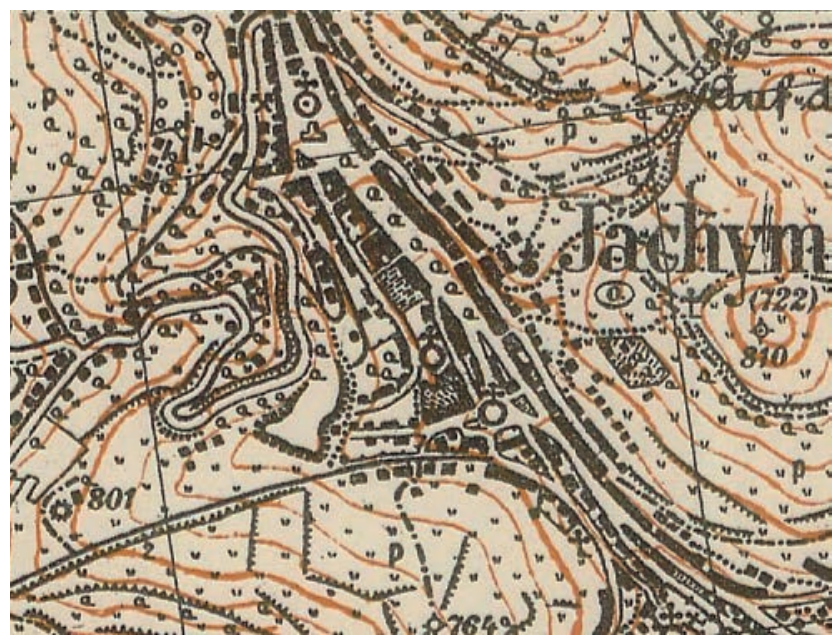

Fig. 9 The centre of Jáchymov on a revised map of the third military survey (1938).

Source: State Administration of Land Surveying and Cadastre

\subsection{The region of Most}

The region around Most has experienced mining for a shorter period than Jáchymov, but to a larger extent and with much more visible changes of landscape due to the type of mining. Starting in the mid-19th century, the mining of lignite (brown coal) was done underground. As the volume grew, it switched to surface mining. The expansion of mining brought rapid population growth. Between 1869 and 1910, the number of inhabitants grew more than six times in some municipalities. As a result, many new buildings appeared around the mines (Kafka 2003; Růžková, Škrabal 2006). For the comparison, the municipality of Souš (the region of Most) was chosen. The map of the Stable Cadastre (figure 12) documents the prevalence of fields (light brown), orchards and meadows (green). In relation to the underground mining, there

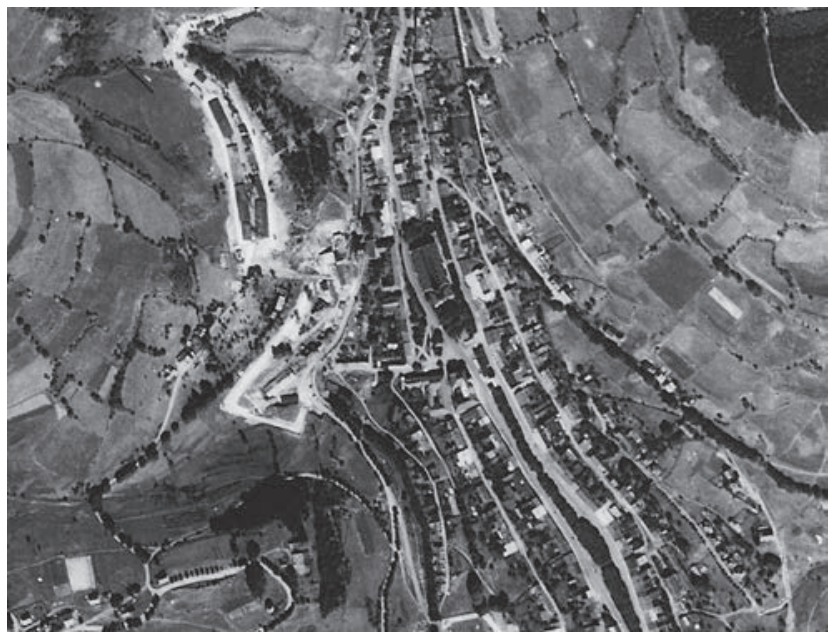

Fig. 10 The centre of Jáchymov in an orthophotograph from 1953. Source: Cenia

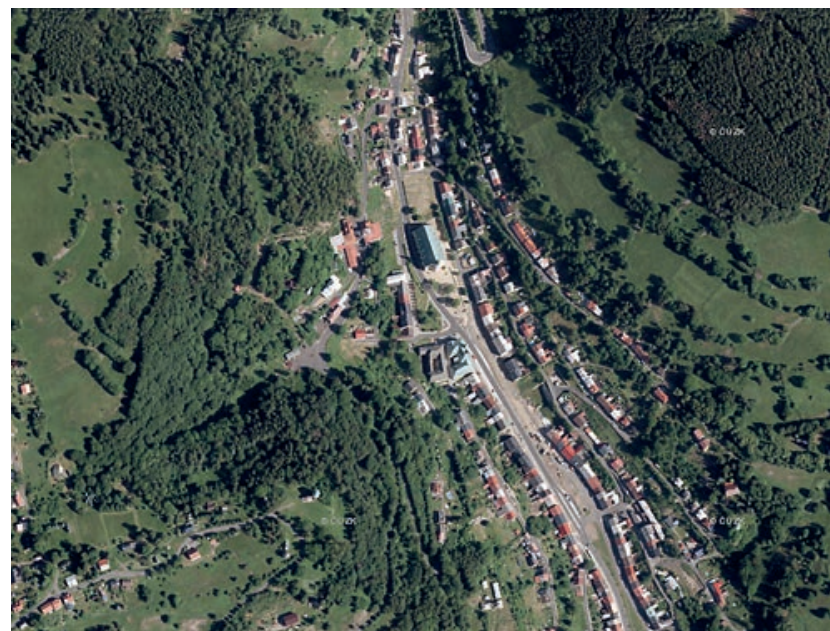

Fig. 11 The centre of Jáchymov in an orthophotograph from 2019. Source: State Administration of Land Surveying and Cadastre

are non-brick buildings (yellow) Sta. Maria Opferung Zech, Sta. Maria Himmelfahrt Zech and St. Antonius $Z e c h$. There is no symbol for the underground mines on the map, unlike on the map of the third military survey from 1938. The map in scale $1: 25,000$ already captures the current surface mines (Kafka 2003). Pingen are visible were the ground collapsed because of the mining activities underground (figure 13). The surface mining is indicated by the mine's borders and hachures. The expanding extraction in open mines and growing soil tips in the area are even more visible in the orthophotograph from 1953 (see the Vrbenský mine and its soil tip in figure 14).

The current landscape in the region of Most is almost completely newly created - as visible in the orthophotograph from 2019 (figure 15). The memory structure of the landscape is kept only in the intangible landscape structure (e.g. the name of the extinct 
village Třebušice is kept in the name of a railway stop on the way from Ústí nad Labem to Chomutov, a Jewish cemetery in Most-Souš that survived because it was, according to the convention, kept away from buildings). Alongside the surface mining of lignite, there has been restoration in progress in the areas where the mining process has finished and on soil tips. The forest and hydric restorations are used - the example is Lake Matylda in the location of the former mine Vrbenský. As the town Most is very close to the area, the restoration of soil tips is specific in regards to the social functions of the new landscape. Lakes are supposed to serve as recreation spots and there is now a racetrack on the restored soil tip of the mine Vrbenský. There are also many roads and railways that make the landscape very fragmented, gigantic industrial projects such are the power plant in Komořany and the petrochemical plant Chemopetrol in Záluží, bucket-wheel excavators, conveyor belts, abandoned mining and industrial operations and buildings. There is a net of surface energy and product conductive pipes (figure 15).

The switch in the public perception of the mining landscape in the region of Most and its history is shown in the common project of two mining companies (Vršanská uhelná and Severní energetická). The project is called Coal Safari (Uhelné safari) and the scope is to provide excursions in the functional mines and the restored areas. The participants can visit the coal mines (mines ČSA and Vršany) and to learn about technical equipment and large machinery. At the same time, the restoration is stressed as well and the landscape changes related to mining are presented (Severní energetická 2020).

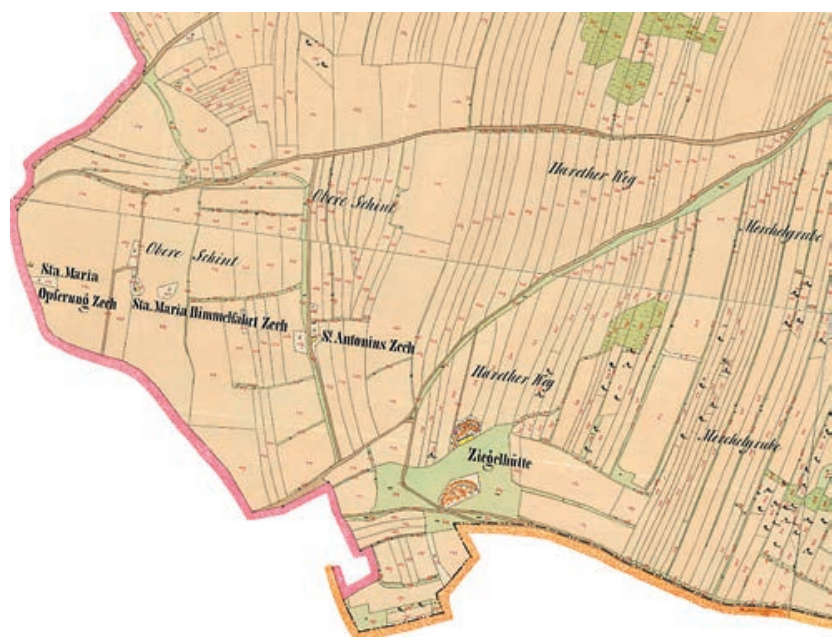

Fig. 12 Underground mining around the village Souš in the Stable Cadastre.

Source: State Administration of Land Surveying and Cadastre

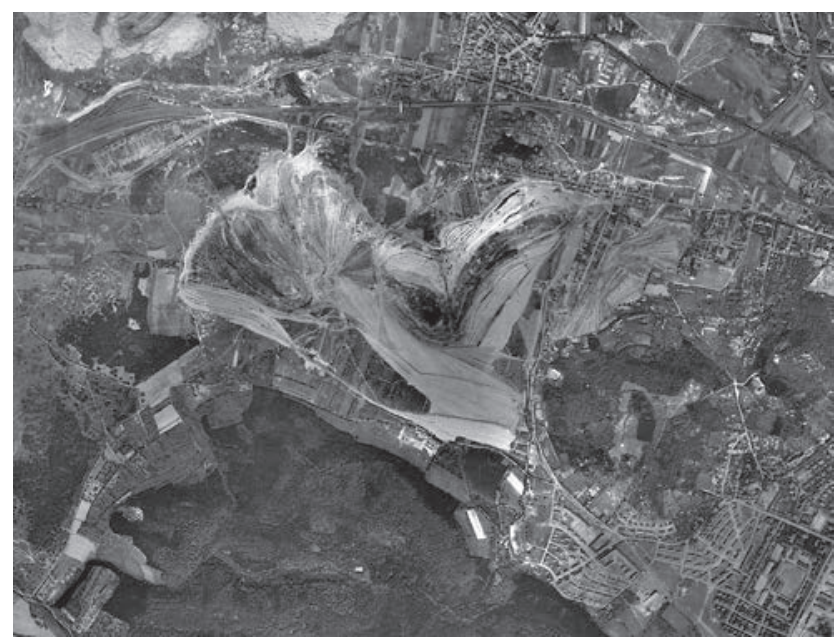

Fig. 14 Surface mining around the former village Souš in an orthophotograph from 1953.

Source: Cenia

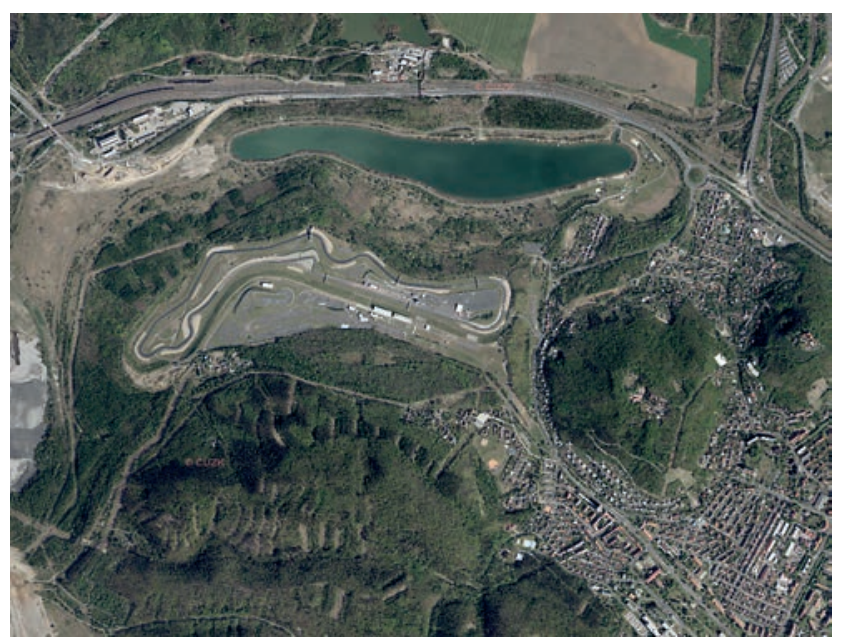

Fig. 15 Restored post-mining landscape around the former village Souš in an orthophotograph from 2019.

Source: State Administration of Land Surveying and Cadastre military survey (1938) Source: State Administration of Land Surveying and Cadastre

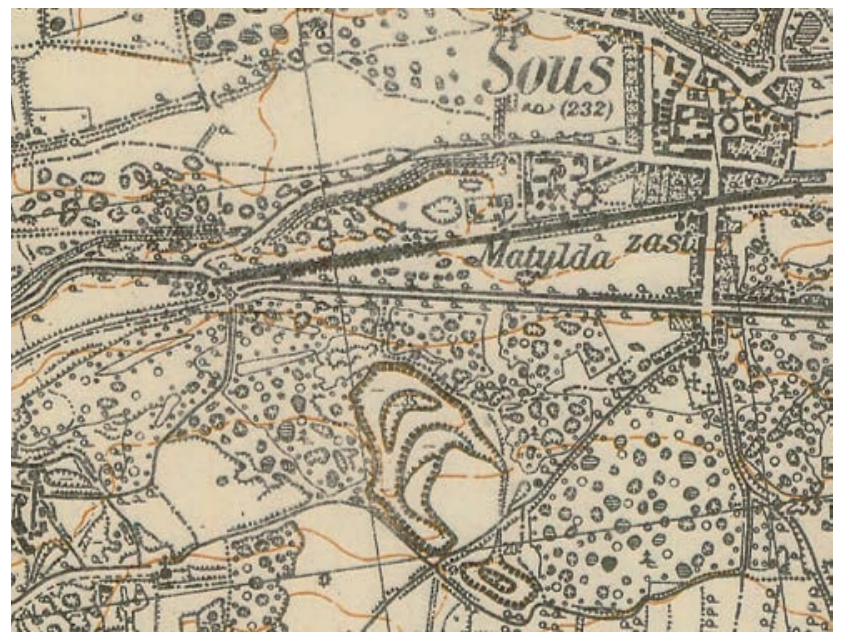

Fig. 13 Surface mining around the village Souš on a map of the third 


\subsection{The region of Kladno}

Until the end of the 18th century, the landscape around Kladno had been agricultural. The maps of the Stable Cadastre show mostly fields, meadows and needleleaf forests around the village Dubí u Kladna (see figure 16). At the end of the 18th century, the first mineral deposits were discovered and the mining started to expand quickly after the beginning of the 19 th century. In 1846, the main coal deposit in the region was discovered and more followed after 1850. An ironworks was founded in 1854 and it was the most important industrial project in the 19th century in the whole Bohemia (Kafka 2003). All these anthropogenic changes in the landscape are visible on the maps of the third military survey. The example in figure 17 shows the creation of the industrial zone and new mines between Kladno, Dubí and Hnidousy (the scale is $1: 25,000$ ). The map includes for instance

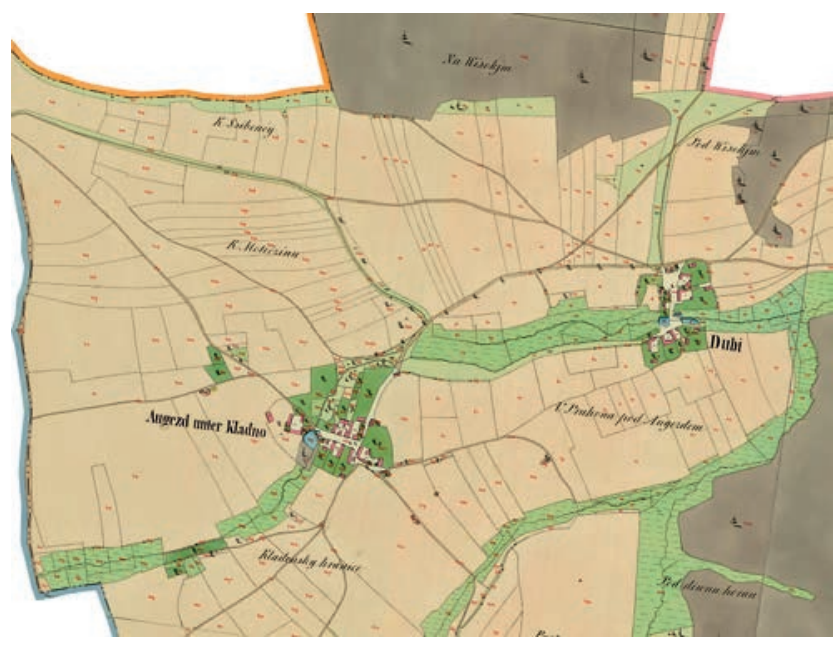

Fig. 16 The surroundings of Dubí in the region of Kladno, a map of the Stable Cadastre.

Source: State Administration of Land Surveying and Cadastre

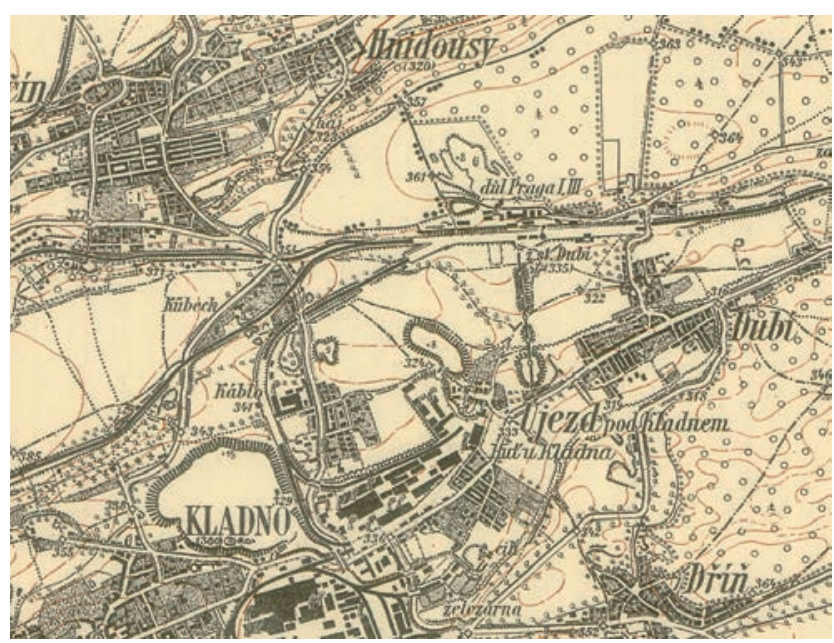

Fig. 17 The surroundings of Dubí in the region of Kladno on a map of the third military survey (1933).

Source: State Administration of Land Surveying and Cadastre smelters, ironworks and mines Praga I and Praga II. Surface mining is indicated by the mines' borders, hachures and information about the height of the material extracted or brought.

At the end of the 19th century, some of the important deposits had been exhausted and the mining activities started to decrease. Ironworks started to be the main economic strength of Kladno. The system of mines was reduced and the industrial areas grew. In Kladno and its parts (Dubí and Hnidousy - nowadays Švermov) experienced rapid population growth. The industrial zone in Kladno is clearly visible in the orthophotograph from 1953 (figure 18). The growth and expansion of Kladno continued to the 20th century, with some slowdowns in times of crises. Reforested soil tips and the current state of the industrial zone (e.g. heating plant, railway station, former company Kablo Kladno) is easily identifiable in the orthophotograph from 2019 (figure 19).

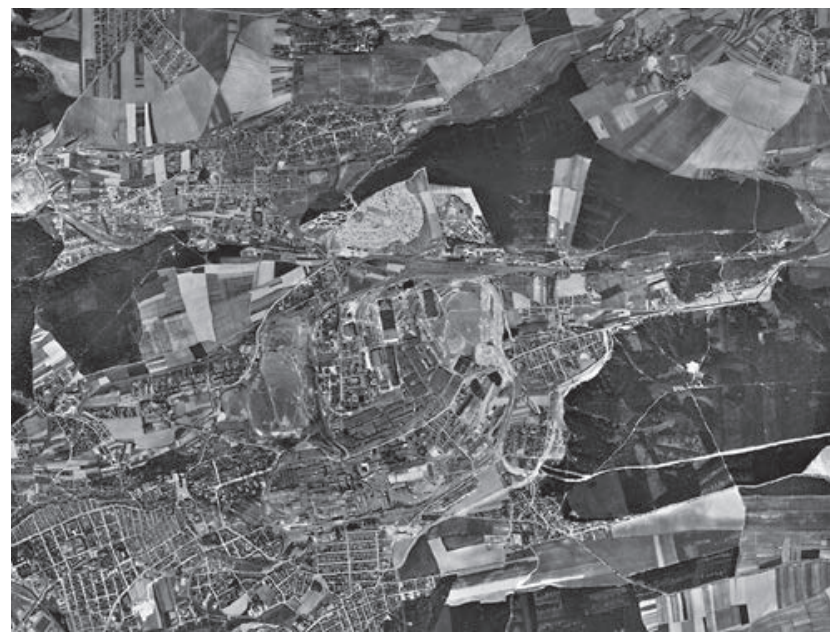

Fig. 18 The surroundings of Dubí in the region of Kladno in an orthophotograph from 1953.

Source: Cenia

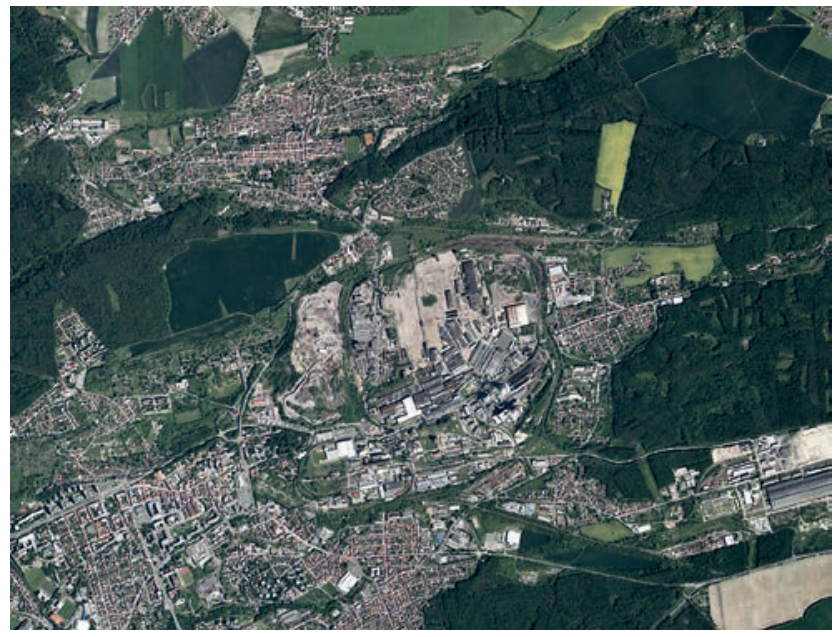

Fig. 19 The surroundings of Dubí in the region of Kladno in an orthophotograph from 2019.

Source: State Administration of Land Surveying and Cadastre 


\section{Conclusion}

The imprints of mining can be found in many places in Czechia. Often, there are landscape elements that are related to mining even though it is not clear at the first sight. Mining causes profound landscape changes that are identifiable dozens of years after it is over. To study the changes, it is important to provide a historical geographical approach where the study of old maps, state map series and their comparison with current sources plays a crucial role.

Each of the sample territories locations has a different history, but all of them have undergone major changes and the original landscape has been turned into a new type of landscape - post-mining landscape. Each area contains different elements and is managed in a different way. In the region of Jáchymov, the mining ended more than 50 years ago and the landscape is perceived as part of cultural heritage (which has been confirmed by the inscription in the UNESCO World Heritage List). The mining in the region was not followed by any significant restoration; the landscape around towns and villages has been basically left without interventions. Today, it is used mainly as a memorial to the mining history and its importance. The extraction of silver in the region of Jáchymov is documented already on the oldest maps (Aretin's map, Vogt's map, Müller's survey of Bohemia - the symbol of crossed hammers, sometimes accompanied by the symbol of the moon). Using the cartographic symbols, the maps provide information about the location of mines and materials extracted. However, none of them provides any detail information on mining landscape elements or the extent of the mining activities. To get such information, it is better to use state map series (military surveys, Stable Cadastre) and orthophotographs from the 1950s onwards. These maps allow us to identify the whole mining area and other mining elements. It is however necessary to take into account that for example the Stable Cadastre labels the remains of mining (e.g. soil tips) as infertile soil. Therefore it is necessary to analyze these areas further and to compare them to other cartographic sources. Naturally, the same is true also for the other two locations examined. These locations have a shorter mining history compared to the region of Jáchymov and therefore it is not possible to identify mining in the oldest maps of these areas.

In contrast, the map series from the second half of the 18th century and newer provide valuable information about type, localisation and extent of mining. Each map series then has its specific characteristics. The Stable Cadastre is in a large scale and it captures the Bohemian lands in the times of agriculture intensification and at the beginning of the Industrial Revolution. Thanks to the scale, it is possible to identify the mines and mining operations. An example can be the symbol for a horse mill on the map of Jáchymov. The maps of the third military survey provide information about the period of intensive industrialization in Bohemia. This is documented for example by co-existence of the finished underground mining and the new surface mining in the region of Most. The military surveys also included both contour lines and spot heights to show the elevation and therefore it is easier to identify the changes in the terrain, such are new soil tips and surface mines.

A unique representation of the landscape is then the map series done in the 1950 s by aerial photogrammetry. Thanks to these pictures it is possible to identify very accurately mining operations and other elements that do not exist anymore. Typical examples are the expansion of mining in the Most region and the labour camps in the region of Jáchymov. The reminder of the existence of the labour camps is an important aspect in the creation of cultural heritage, because it is part of history and it should not be forgotten. Thanks to the comparison of aerial photographs, it is possible to reconstruct the landscape and to remember the events that have taken place there (Hloušek 2017).

Mining is one of the most important landscape forming processes. The identification of processes and remains helps us to understand the current state of the landscape and it can also help in decision-making and in the creation of cultural heritage.

\section{Acknowledgements}

This article is an output of project DG18P020VV008 "Dědictví zaniklých krajin: identifikace, rekonstrukce a zpř́ístupnění" (Heritage of Lost Landscapes: Identification, Reconstruction and Presentation) that is supported within the Program of the Ministry of Culture of the Czech Republic for the support of applied research and experimental development of national and cultural identity for the years 2016 to 2022 ("NAKI II").

\section{References}

Antrop, M. (2005): Why landscapes of the past are important for the future. Landscape and Urban Planning 70, 21-34, https://doi.org/10.1016/j.landurbplan 2003.10.002.

Ashworth, G. J., Graham, B. (1997): Heritage, Identity And Europe. Journal of economic and Social Geography 88(4), 381-388, https://doi.org/10.1111/j.1467-9663.1997 .tb01632.x.

Bayer, T., Potůčková, M., Čábelka, M. (2009): Cartometric Analysis of old maps on example of Vogt's Map. In: ICA Symposium on Cartography for Central and Eastern Europe, LNG\&C, 509-522, Vienna, Springer, https://doi .org/10.1007/978-3-642-03294-3_33.

Bayer, T., Potůčková, M., Čábelka, M. (2009): Kartometrická analýza starých map českých zemí: mapa Čech a mapa Moravy od Petra Kaeria. Geografie: Sborník České 
geografické společnosti 114(3), 230-243, https:// doi.org/10.37040/geografie2009114030230.

Bridge, G. (2004) Contested terrain: Mining and the environment. Annual Review of Environment and Resources 29, 205-259, https://doi.org/10.1146 /annurev.energy.28.011503.163434.

Cole, D. (2004) Exploring the sustainability of mining heritage tourism. Journal of Sustainable Tourism 12(6), 480-494, https://doi.org/10.1080 /09669580408667250.

Conlin, M. V., Jolliffe, L., eds. (2014): Mining Heritage and Tourism: A Global Synthesis. Routledge, London and New York.

Conesa, H. M., Schulin, R., Nowack, B. (2008): Mining landscape: a cultural tourist opportunity or an environmental problem? The study case of the Cartagena - La Unión Mining District (SE Spain). Ecological Economics 64, 690-700, https://doi.org/10.1016 /j.ecolecon.2007.06.023.

Coupland, B., Coupland, N. (2014) The authenticating discourses of mining heritage tourism in Cornwall and Wales. Journal of Sociolinguistics 18(4), 495-517, https://doi.org/10.1111/josl.12081.

Daugstad, K., Grytli, E. (1999): How to study and manage a multihistoric landscape. Norsk Geografisk Tidsskrift 53, 85-92, https://doi.org/10.1080/00291959950136803.

Harvey, D. C. (2008) The history of heritage. In: Graham, B. and Howard, P. (Eds.) The Ashgate Research Companion to Heritage and Identity. Aldershot, Ashgate, 19-36.

Hauserová, M., Poláková, J. (2015): Pomůcka pro používání základních historických map pro studenty FA ČVUT, ČVUT, Praha.

Hewison, R. (1987): The heritage industry: Britain in a climate of decline, Methuen, London.

Hloušek, J. (2017): Jáchymov - Joachimsthal. Jáchymov, Marten.

Jelen, J. (2018): Mining Heritage and Mining Tourism. Czech Journal of Tourism 7(1), 93-105, https://doi.org/10 .1515/cjot-2018-0005.

Jelen, J., Chromý, P. (2018): Krušnohoří jako součást světového dědictví UNESCO? Geografické rozhledy 27(5), 30-33.

Jelen, J., Kučera, Z. (2017): Approaches to identification and interpretation of mining heritage: the case of the Jáchymovsko area, Ore Mountains, Czechia. Hungarian Geographical Bulletin 66 (4), 321-336, https://doi.org /10.15201/hungeobull.66.4.4.

Kafka, J. (2003): Rudné a uranové hornictví České republiky. Ostrava, Anagram.

Karel, T., Kratochvílová, A., eds. (2013): Proměny montánní krajiny. Historické sídelní a montánní struktury Krušnohoří. Národní památkový ústav, Loket.

Kuchař, K. (1959): Mapy českých zemí do poloviny 18. století. Vývoj mapového zobrazení území Československé republiky I. Praha, Ústřední správa geodézie a kartografie.

Kuchař, K. (1967): Mapové prameny ke geografii ČSR. Acta Universitatis Carolinae Geographica 2(1), 57-97.

Kuchař, K., Roubík, F. (1936): Regni Bohemiae Nova et Exacta Descriptio MDCXIX: (Renov. Daniel Wussin MDCLXV.): Text k listu 3 a 3a. Praha: Geografický ústav Karlovy university. 15 s. Monumenta cartographica Bohemiae
Marcucci, D. J. (2000): Landscape history as a planning tool. Lanscape and Urban Planning 40(1-2), 67-81, https:// doi.org/10.1016/S0169-2046(00)00054-2.

Niederöst, J. (2004): Image analysis for the history of cartography: Drawing conclusions from the evaluation of Pfyffer's Relief. The International Archives of Photogrammetry, Remote Sensing and Spatial Information Sciences, Volume XXXV, Part B5, Commission V, Presented at XXth ISPRS Congress in Istanbul, Turkey, 389-394.

Novotná, E., Tröglová Sejtková, M., Čábelka, M., Paták, J. (2020): Aretinova mapa Českého království. Karolinum, Praha.

Plánka, L. (2014): Dějiny zeměměřictví, Vysoká škola Báňská, TU Ostrava

Potůčková, M., Bayer, T. (2012): Application of e-learning in the TEMAP project. Geoinformatics FCE CTU, 2012/9(9), 91-99, https://doi.org/10.14311/gi.9.8.

Růžková, J.; Škrabal, J. (2006): Historický lexikon obcí České republiky 1869-2005. Praha, Český statistický úřad.

Semotanová, E. (2001): Tematické legendy tištěných map Českých zemí ve století Jana Kryštofa Müllera. Historická geografie, 31.

Semotanová, E. (2001): Mapy Čech, Moravy a Slezska v zrcadle staletí. Praha, Libri.

Semotanová, E. (2006): Historická geografie českých zemí. Praha, Historický ústav

Schenk, W. (2011): Historische Geographie. Darmstadt, WBG.

Tůmová, M. (2018): Maps of estates in Bohemia as an example of an undervalued historical geographice source - research survey and examples of utilization. AUC Geographica 53(2), 238-251, https://doi.org/10.14712 /23361980.2018.22.

Turnpenny, M. (2004): Cultural Heritage, an III-defined Concept? A Call for Joined-up Policy. International Journal of Heritage Studies 10(3), 295-307, https:// .org/10.1080/1352725042000234460.

Win, N. T. (2014): Historical Mapping Method: New Research Method for Research Methdology. ICMR Journal 2(2), 57-76.

\section{Internet sources}

Geoportal ČUZK: Orthophoto of the Czech Republic [online]. [downloaded 6. 5. 2020] https://geoportal.cuzk.cz

Northern Energy: Coal safari [online]. [downloaded 28. 4. 2020] https://uhelnesafari.cz

UNESCO World Heritage List. [online]. [downloaded 25. 4. 2020] http://whc.unesco.org/en/list

VGHMÚř in Dobruška: Aerial photographs [online]. [downloaded 20.4. 2020] https://lms.cuzk.cz/lms/lms _prehl_05.html

\section{Map sources}

CENIA, Czech Environmental Information Agency: Czech National Geoportal INSPIRE, https://geoportal.gov.cz /web/guest/map (Orthophoto from 1953)

Map Collection, Faculty of Science, Charles University, http://www.mapovasbirka.cz (Aretin's, Vogt's and Müller's map of Bohemia)

Czech Office for Surveying, Mapping and Cadastre, http:// www.cuzk.cz (Orthophoto of the Czech Republic from the present time) 